\title{
Ciência, saúde e público
}

Os últimos anos foram marcados por um aumento de interesse por parte da comunidade científica em ampliar seus horizontes de comunicação, dirigindo-se não apenas a seus pares, mas, também, à sociedade como um todo para falar de temas da ciência e da saúde. Não se trata de uma iniciativa isolada. Ao contrário, trata-se de um esforço que incorpora muitos atores - cientistas, profissionais da saúde, professores do ensino básico e médio, jornalistas, divulgadores da ciência de uma forma mais geral e outros - que vem se intensificando desde a década de 80.

Neste movimento, instrumentos diversos são usados, desde os mais usuais (como revistas, jornais diários, rádio e TV) até os mais provocativos (eventos públicos em bares e outros locais fora do âmbito acadêmico, peças de teatro, histórias em quadrinhos, poesias, cordéis, jogos, contação de história, festivais de ciência etc.), passando pelo uso das novas tecnologias (Internet, multimídias etc.). Ressalte-se, ainda, os museus e centros de ciência interativos, que vêm eclodindo em todo o país e hoje já atingem aproximadamente uma centena. Em particular na área da saúde, merecem destaque os programas especialmente voltados para populações carentes, visando a socializar e disseminar informações relacionadas a doenças, prevenção das mesmas e estratégias de melhorar a saúde pública.

Além disto, percebemos, em particular nos últimos anos, um crescimento no número de encontros que reúnem os diferentes atores para analisar e discutir estratégias para aperfeiçoar a atividade de comunicar temas da ciência e da saúde. Só na América Latina, vários países já organizaram encontros desse tipo em 2003, entre eles Argentina (http:// www.scidev.net/ $\mathrm{News/index.cfm?fuseaction=readnews \& itemid=985 \& language=1),} \mathrm{Bolívia}$ (http://www.adital.org.br/asp2/ noticia.asp?idioma=PT\&noticia=8695), Brasil (http:// eventos. bvsalud.org/scicom/pt/homepage.htm e http:// www.orbicom.uqam.ca/in_focus/ conferences/pdf/comsaude2003.pdf), Chile (http:// www.mideplan.cl/milenio/noticia_04.htm), Costa Rica (http:// www.cientec.or.cr/ ciencias/taller.html) e México (http:// www.redpop. org/8reunion/res_8areunion.html), só para citar alguns. A profissionalização do comunicador de temas de ciência e da saúde também é constantemente colocada em pauta.

A divulgação da ciência e da saúde ganhou espaço, ainda, na agenda política. Ilustra bem isto o fato de que um plano brasileiro de popularização da ciência foi incluído no programa do Presidente Lula na época das eleições e que começa agora a ser discutido. Recentemente, também no Brasil, órgãos como o Ministério da Ciência e Tecnologia, o Conselho Nacional de Desenvolvimento Científico e Tecnológico (CNPq), a Financiadora de Estudos e Projetos (FINEP) e algumas fundações de amparo à pesquisa têm destinado recursos para a divulgação da ciência e da saúde.

Este movimento reflete a percepção crescente da importância de integrar melhor ciência, saúde coletiva e sociedade. Se queremos uma sociedade saudável e desenvolvida cientificamente, esta deve ser bem informada sobre os temas da ciência e da saúde. Mas para semear uma cultura saudável de ciência e saúde pública não basta dar ao público as "pílulas do saber", como as que eram passivamente ingeridas pelos personagens de J onathan Swift que percorreram as Viagens de Gulliver. Trata-se de uma tarefa bem mais complexa que precisa considerar o público como um ator importante deste processo de divulgação da ciência e da saúde, de forma que passe a ter uma atuação crítica e participativa diante do conhecimento e dos processos decisórios.

Luisa Massarani

Centro de Estudos do Museu da Vida, Casa de Oswaldo Cruz,

Fundação Oswaldo Cruz, Rio de Janeiro, Brasil.

http://www.museudavida.fiocruz.br 


\section{Science, health, and the public}

Recent years have witnessed a boom in the scientific community's interest in expanding its communications horizons, focusing not only on peers but also on society as a whole in the discussion of science and health-related issues. This is not an isolated initiative. On the contrary, particularly since the 1980s there has been a concerted effort by many players - scientists, health professionals, primary and secondary teachers, journalists, science communicators, and others.

Various instruments are currently being used, ranging from the most common (like magazines, daily newspapers, radio, and television) to the more provocative (public events in bars and other venues and channels outside the academic circuit, theater plays, comic books, poetry, country music, games, story-telling, science fairs, etc.) and encompassing new technologies (like the Internet and multimedia). An outstanding role has been played by interactive science museums and centers which have sprung up all over Brazil and now number approximately one hundred. Particularly in the health field, there are outstanding programs targeting low-income communities, aimed at sharing and disseminating information on diseases and their prevention, as well as strategies to improve public health.

In addition, and especially in recent years, we have seen an increase in the number of meetings of different players convening to analyze and discuss strategies to enhance communications in science and health issues. In Latin America alone, several countries have organized such meetings in 2003, including Argentina (http:// www.scidev.net/ News/index.cfm?fuseaction $=$ readnews\&itemid $=985 \&$ language $=1$ ), Bolivia (http:/ / www. adital.org.br/asp2/ noticia.asp?idioma=PT\&noticia=8695), Brazil (http:// eventos.bvsalud.org/ scicom/pt/homepage.htm) and (http://www.orbicom.uqam.ca/in_focus/conferences/ pdf/comsaude2003.pdf), Chile (http:// www.mideplan.cl/milenio/noticia_04.htm), Costa Rica (http:// www.cientec.or.cr/ciencias/taller.html), and Mexico (http:// www.redpop. org/8reunion/res_8areunion.html), to mention just a few. Professional training for science and health communicators has also been a constant item on the agenda.

Public communication of science and health issues has also gained increasing prominence on the political agenda. Illustrating this trend is the fact that a Brazilian plan for popularizing science was part of now-President Lula's campaign platform in 2002, and the plan's implementation is currently being discussed in his Administration. Recently in Brazil, government agencies like the Ministry of Science and Technology, the National Research Council (CNPq), the Funding Agency for Studies and Projects (FINEP), and several State research support foundations have allocated resources for the public dissemination of science and health themes.

This trend reflects a growing perception of the importance of enhanced integration between science, public health, and society. If Brazil intends to have a healthy and scientifically developed society, such a society must be well-informed on science and health themes. Yet in order to spread a healthy culture in science and public health, it will not suffice to give the public the kinds of knowledge pills that were passively swallowed by Jonathan Swift's characters in Gulliver's Travels. The task is much more complex, and requires incorporating the public as an important player in this process of disseminating science and health, in such a way that it takes a critical and participatory stance towards knowledge and decision-making processes.

Luisa Massarani

Centro de Estudos do Museu da Vida, Casa de Oswaldo Cruz,

Fundação Oswaldo Cruz, Rio de Janeiro, Brasil.

http://www.museudavida.fiocruz.br 